\title{
Shifts in Translation of English Noun Phrases into Indonesian with Reference to the Short Story A Scandal in Bohemia
}

\author{
Harvin Thedeolin Finsen*, Ida Ayu Made Puspani \\ English Department, Faculty of Arts, Udayana University \\ [harvintf@gmail.com], [dayupuspani@gmail.com] \\ Denpasar, Bali Indonesia \\ *Corresponding Author
}

\begin{abstract}
Shifts in translation of English noun phrases into Indonesian with reference to the short story A Scandal in Bohemia is a study of how to transfer message and information from one to another language to overcome its language barrier. Due to the systematic difference of every language, the occurrence of the translation shift is unavoidable in order to make the translation product natural. Translation shift and meaning equivalent are two core elements in translation that are correlated and inseparable. This study was conducted to find out the types of translation shifts and their implications towards the meaning equivalents found in the short story "A Scandal in Bohemia". The data were taken from a short story entitled "A Scandal of Bohemia" using the documentation and note-taking techniques. In addition, the data were analysed qualitatively and comparatively. They were classified based on the types of shifts and the analysis of its implication towards the meaning equivalent using the theory of Translation Shift proposed by Catford (1965 and Theory of Meaning-Based Translation proposed by Larson (1998). This study revealed that the occurrence of the translation shift can be classified into four types of shift namely structure shift, class shift, unit shift and intra-system shift, all of which belong to the category shift. None of the data showed level shift occurrence. This study also revealed, as what Catford (1965) has stated in his theory, that the most frequent shift is the structure shift, meanwhile the least one is the class shift. Multiple shifts also occurred in some of the NPs. There are a few pairs namely unit and class shifts, class and intra-system shifts, unit and intra-system shifts and structure and intra-system shifts. Furthermore, the implication of translation shift towards the meaning equivalent is also the core aspect in this study; it is shown that the occurrence of the shift is obligatory in order to make the translation product natural and the meaning carried from the SL to the TL is held constant and relevant to the feature of substance.
\end{abstract}

Keywords: translation, meaning-equivalence, shift, noun phrase

\begin{abstract}
Abstrak
Penelitian ini berjudul pergeseran dalam terjemahan frasa kata benda bahasa Inggris ke bahasa Indonesia dengan merujuk pada sebuah cerita pendek. Sebuah Skandal di Bohemia adalah studi tentang cara mentransfer pesan, informasi dari satu bahasa ke bahasa lain untuk mengatasi kendala bahasanya. Karena perbedaan sistematik dari setiap bahasa, terjadinya pergeseran terjemahan tidak dapat
\end{abstract}


dihindari untuk membuat hasil terjemahan alami. Pergeseran terjemahan dan padanan makna adalah dua elemen inti dalam penerjemahan yang berkorelasi dan tidak dapat dipisahkan, penelitian ini dilakukan untuk mengetahui jenis-jenis pergeseran terjemahan dan implikasinya terhadap padanan makna yang ditemukan dalam cerpen pendek "A Scandal in Bohemia". Data diambil dari sebuah cerita pendek berjudul "A Scandal of Bohemia" menggunakan dokumentasi dan teknik mencatat. Selain itu, data dianalisis secara kualitatif dan komparatif. Data kemudian diklasifikasikan berdasarkan jenis pergeseran dan analisis implikasinya terhadap makna yang setara dengan menerapkan teori Terjemahan Pergeseran yang diusulkan oleh Catford (1965) dan Teori Terjemahan Berbasis Makna yang diusulkan oleh Larson (1998). Studi ini mengungkapkan bahwa terjadinya pergeseran terjemahan dapat diklasifikasikan ke dalam empat jenis pergeseran yaitu pergeseran struktur, pergeseran kelas, pergeseran unit dan pergeseran intrasistem di mana mereka semua termasuk dalam kategori pergeseran. Tidak ada data yang menunjukkan terjadinya pergeseran level. Penelitian ini juga mengungkapkan bahwa sebagaimana yang dinyatakan oleh Catford (1965) dalam teorinya bahwa pergeseran yang paling sering adalah pergeseran struktur, sedangkan yang paling sedikit adalah pergeseran kelas. Pergeseran ganda juga terjadi di beberapa frasa kata benda, ada beberapa pasangan yaitu : pergeseran unit dan kelas, pergeseran kelas dan intra-sistem, pergeseran unit dan intra-sistem dan struktur dan pergeseran intra-sistem. Lebih lanjut, implikasi pergeseran terjemahan terhadap makna yang setara juga merupakan aspek inti dalam penelitian ini; ditunjukkan bahwa terjadinya pergeseran adalah wajib untuk membuat terjemahan yang setara dan alami dengan makna yang dipindahkan dari SL ke TL tetap utuh dan relevan dengan fitur substansi.

\section{Kata kunci: terjemahan, arti-kesetaraan, shift, frasa kata benda}

\section{Background of the Study}

Translation has become one of the most important aspects of human being, especially in this modern era. The fact that there are no more boundaries among the countries to access the information provided on the internet, magazines, articles, literary works and many other forms of information. But every country has a different language so that translation is necessary here, as a means of transferring the message of information in particular references to the target language.

The fact that all of the information is mostly in English is undeniable. As an international language, English has been the most prominent language to be used internationally. Consequently, the globalization makes every piece of information in the world can spread easily world-wide due to the technological sophistication which provides internet as one of the main access. Translation is the only one that helps transfer message from English to another language. Besides, mastering English, in this case, can be said as a must in order to provide a proper translation.

As a matter of fact, due to its prominence, translation is viewed differently. Translation is a process and a product. Catford (1965) states that translation is the replacement of a textual material in one language (SL) by equivalent textual material in another language (TL). From this definition, it can be said that translation is an activity that produces a product which is the translated text that reaches us. Larson (1998) in his theory of Meaning-based translation stated that it consists of transferring the meaning of the source language into the receptor language, by going from the form of the first language to the form of a second language by way of semantic structure and the meaning 
has to be held constant. Foster (1958) states that translation is an act through which the context of a text is transferred from the source language into the target language. Meanwhile, Nida contributed his theory of translation by bringing up two 'equivalence waya' as guideline to translation; they are 'dynamic equivalence' and 'formal equivalence'. Formal equivalence here focuses on the need to pay attention to the form and content in the message that in the target language should be in accordance with the different parts of the original language. While dynamic equivalence only tends to transfer the meaning of the SL, not the grammatical form.

Translation shift itself represents some changes occurring in a translation process, it occurs both in the lower level of language, just like the lexicogrammar, and in the higher thematic level of text. Catford states that translation shift is done in order to make the natural equivalent which means that the language that is translated to the target language has to be natural and as similar as possible to the source language even though, there is no exact equivalence. Ever since the globalization, translation is considered very necessary to exchange information from one to another language, for there are only a few countries that use the same language. The translation role is a major means of communication of inter-countries. As in Indonesia, the evidence can be seen from how many short stories, movies and any other literary works that have been translated from one language into Indonesian although the fact is that most of them are originally written in English.

Considering the significance of translation for international communication especially in Indonesia, this study is dedicated to identifying the types of translation shift and its implication towards the meaning equivalence in the translation of English noun phrases into Indonesian with a reference to the short story A Scandal in Bohemia.

\section{Problem of the study}

Based on the background of the study, there are two problems formulated as follows:

a. What types of shift occur in the translation of the English NP into Indonesian in the short story A Scandal in Bohemia?

b. What are the implications of the shift towards the meaning equivalent?

\section{Aims of the Study}

Based on the formulated problems above, this study was conducted in order to meet the following purposes:

a. To analyze the types of shift occurring in the translation of the English NP into Indonesian in the short story "A Scandal of Bohemia".

b. To find out the implication of the shift towards the meaning equivalent in Indonesian.

\section{Research Method}

Due to the large scope and the complexity of the topic, this study focuses on investigating the shifts in translation of English noun phrases found in the short story A Scandal in Bohemia. Specifically, this study focuses its analysis in line with the problems of the study, that is, the types of shifts and their implication towards the meaning equivalent in Indonesian.

\subsection{Data source}

The data of the study were taken from the internet which was downloaded on a website https://sherlock-holm.es/ which provides the original short story of A Scandal in Bohemia written by Sir Arthur Conan Doyle which was first published on 25 June 1891 by The Strand Magazine; it was the first of the stories 
collected in The Adventures of Sherlock Holmes in 1892.

Meanwhile, the Indonesian version "Seri Pertualangan Sherlock Holmes \& 5 Kasus Paling Misterius" was translated by Sri Wulandari M (2018). This shortstory contains many noun phrases needed for the analysis. Besides, this story is easily understood and it has its translated version into Indonesian language. Therefore, this short story was chosen as the data of this study. The secondary data of this study are some books about the translation shift and equivalence.

\subsection{Method and Technique of Collecting Data}

The data were collected through library study using the documentation method. A few techniques such as note taking and detailed reading were applied in this study. Documentation method is usually done in collecting the data related to books, notes, newspaper, transcription, movie subtitles and the others.

In collecting the data, several steps were conducted. The first step was reading the story in the source language to understand the short story comprehensively. After understanding the story, all the NPs were noted down and classified based on their types; the data were noted by note-taking technique. Consequently, the equivalents of the NPs in the TL were matched to the SL NPs.

\begin{tabular}{lll}
\hline \multicolumn{2}{l}{$\begin{array}{l}\text { Source } \\
\text { Language }\end{array}$} & Target Language \\
\hline 1. & $\begin{array}{l}\text { To Sherlock } \\
\text { Holmes she is }\end{array}$ & $\begin{array}{l}\text { Holmes, Sherlock } \\
\text { always the ini memang luar } \\
\text { woman }\end{array}$ \\
\hline
\end{tabular}

The data were presented in parallel corpora where the SL NP is placed alongside with the TL NP, as a means of comparison and to find out the shift occurrence. Then, the data were randomly picked from each category of the shift for the main analysis of this study.

\subsection{Method and Technique of Analysing Data}

The collected data were analyzed using descriptive qualitative method. The data were analyzed using some theories. The first problem, that is, the types of shifts occurring in the translation of English NP into Indonesian were analyzed using the theory proposed by Quirk, et.al (1973) about English grammar used to analyze the English noun phrase structure and theory proposed by Alwi, et, al. (1998) used to analyze Indonesian noun phrase structure.

Meanwhile, the second problem which is the implication of the shift towards the meaning equivalence was analyzed using the theory proposed by Larson (1998) about meaning-based translation and the theory proposed by Catford (1965) about translation shift with specific discussion on translation equivalence. The data analysis was focused on the types of the shift and itheir equivalents that occur in the particular short story. The relevant data were classified based on the types of shifts. After the analysis of the shift occurrence, the meaning equivalence is discussed.

\subsection{Method and Technique of Presenting the Analysis}

In presenting the final result of this study, it is presented by informal method. The analysis of the data is presented in the form of table below:

\section{Structure Shift}

The analysis of the Noun Phrase can be seen as follows :

\begin{tabular}{llll}
\hline $\begin{array}{l}\text { English } \\
\text { Phrase }\end{array}$ & Noun & $\begin{array}{l}\text { Indonesian } \\
\text { Phrase }\end{array}$ & Noun \\
\hline $\begin{array}{l}\text { Det. } \\
\text { (Modifier) }\end{array}$ & $\begin{array}{l}\text { (Head) } \\
\text { N }\end{array}$ & Modifier \\
\hline The & Woman & Wanita & Ini \\
\hline
\end{tabular}


The bold-printed English NP The Woman of the SL is translated to Wanita Ini in the TL. The internal structure of SL seems to be different with the TL, This translation revealed structure shift. The diagram below shown how the structure changed :

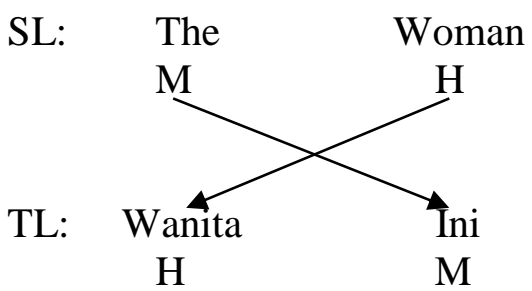

The diagram above revealed that the structure shift happen in a way to make the translation equivalent, as Catford states that "The translation shift done in order to get the natural equivalent of the source text message into the target text (1965: 76). The structure changed from SL to TL from MH to HM. If only the source structure was kept by the translator, the woman will be translated into ini wanita, it became a literal translation that sound unnatural. (Larson, 1998). The structure shift was obligatory because of the difference structure between the SL and TL.

Woman here functions as $\mathrm{H}$ and The as the $\mathrm{M}$, the structure of the NP is $\mathrm{MH}$. 'The Woman' consists of an article 'the' which stands as the modifier and also categorized as a definite article that refers to a specific identity known and 'Woman' is a singular noun that refers to a lady.

This NP is translated into wanita ini in the TL. Woman is translated into wanita and the is translated into ini. As stated in the theory proposed by Alwi, et, al. about Indonesian noun phrase, a noun in the Indonesian language can be expanded in the initial or the final position (left or right) as long as the formulation is ended by 'ini' or 'itu' (Alwi, et. al., 1998) which sta nds as the demonstrative pronoun. In this case the
Indonesian NP is ended by ini refers to the SL the to modify the $\mathrm{H}$.

According to Merriam-Webster dictionary, Woman means an adult female person and as in the SL, KBBI (The official Indonesian dictionary) explains wanita as 'perempuan dewasa' which means 'female'. As a result, Wanita is the formal correspondence of Woman as it is the exact equivalent and natural translation in the SL. Therefore, the translation is equivalent, as the meaning is held constant (Larson, 1998).

5. Analysis of the Shifts in the Translation of English Noun Phrases into Indonesian with Reference to the Short Story A Scandal in Bohemia

\subsection{Structure Shift}

\begin{tabular}{lll}
\hline No & $\begin{array}{l}\text { Source } \\
\text { Language }\end{array}$ & Target Language \\
\hline 01. & "My & "Pernikahanku \\
& marriage had & menjauhkan kami \\
& drifted us & satu sama lain" (p. \\
& away from & 02) \\
& each other \\
& \\
(p. 03) & \\
\hline
\end{tabular}

The analysis of the Noun Phrase can be seen in the table below :

\begin{tabular}{llll}
\hline $\begin{array}{l}\text { English } \\
\text { Phrase }\end{array}$ & Noun & $\begin{array}{l}\text { Indonesian } \\
\text { Phrase }\end{array}$ & Noun \\
\hline $\begin{array}{l}\text { Modifi } \\
\text { er }\end{array}$ & $\begin{array}{l}\text { Noun } \\
\text { (Head) }\end{array}$ & $\begin{array}{l}\text { Noun } \\
\text { (Head) }\end{array}$ & $\begin{array}{l}\text { Noun } \\
\text { (Modifie } \\
\text { r) }\end{array}$ \\
\hline My & Marriag & $\begin{array}{l}\text { Pernikah } \\
\text { an }\end{array}$ & -ku \\
& e & an & \\
\hline
\end{tabular}

The English NP My Marriage is translated into Pernikahanku in Indonesian. The structure of the SL and the TL are different due to the systematic difference between these two languages; this translation reveals structure shift. Catford defined structure shift as a shift indicated by a situation in which there are two languages which have different structural elements. Besides, the source 
language and target language should have formal correspondence. Simply, it means that it's the change of the grammatical structure from the SL to the TL; structural changes must occur. In this case, the structure shift happens from $\mathrm{MH}$ to HM. The structural change can be seen below:

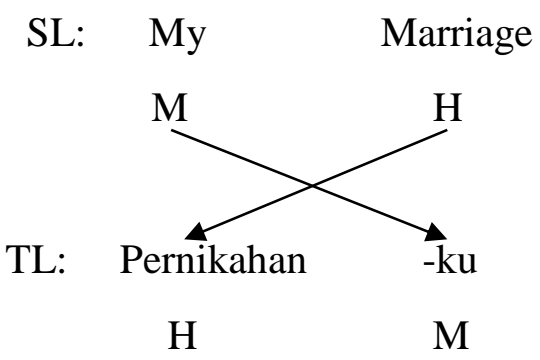

The English NP My Marriage of SL is translated into Pernikahanku in the TL. $M y$ is the modifier and Marriage is the Head thus the structure of this NP is MH. According to the Oxford Dictionary, My is the possessive pronoun of $I$ which emphasizes ownership.

Marriage here is translated into pernikahan and the suffix $-k u$ ' is a possessive pronoun originating from the word $a k u$ (means; $I$ ) and the suffix $-k u$ is usually added to the Indonesian word to address the belonging of the speaker. The translation in the TL Pernikahan is N which is the same word class as the SL N. As a result, pernikahan is the formal correspondence of marriage as its equivalent and natural translation in the SL.

Therefore, the translation is equivalent and the meaning is held constant (Larson, 1998). It is also relevant because the translated meaning of SL and TL text or item are related to the same features of substance (Catford, 1965).

\subsection{Unit Shift}

\begin{tabular}{lll}
\hline No & $\begin{array}{l}\text { Source } \\
\text { Language }\end{array}$ & $\begin{array}{l}\text { Target } \\
\text { Language }\end{array}$ \\
\hline 01. & One night - It & Suatu malam aku \\
was on the & melewati Baker \\
twentieth of & Street - tanggal \\
March, 1888 - dua puluhan & dua \\
I was returning & bulan maret 1888 \\
from a journey & - saat itu aku \\
to a patient (p. & sedang dalam \\
03) & perjalanan pulang \\
& dari kunjungan \\
& ke seorang \\
& pasien. (p. 04) \\
\hline
\end{tabular}

From the table above, a unit shift can be found from the SL. The NP a journey (phrase) is translated into kunjungan (word) in TL, the unit shift occurs from a phrase to a word. It's proven that the unit shift occurs from the SL to the TL as Catford (1965) defined that unit shift is a change of rank, departures from formal correspondence in which the translation equivalent of a unit at one rank in the SL is a unit at a different rank in the TL (Catford, 1965: 79). The occurrence of the unit shift can be seen below:

SL: a journey (phrase)

\section{TL: Kunjungan (word)}

The English NP a journey is translated into kunjungan in Indonesian as NP. It has the structure of MH; this NP is preceded by the indefinite article a that specifies a single unit of measure; in this case, it emphasizes that the $\mathrm{H}$ is a single journey. According to the MerriamWebster Dictionary, journey means 'something suggesting travel or passage from one place to another'.

It is translated into kunjungan in Indonesian. This translation does not imply the actual meaning of journey, as in English it means visit. In fact, it is considered the possible closest meaning as in the context of the source language 


\begin{tabular}{lll}
\hline No & $\begin{array}{l}\text { Source } \\
\text { Language }\end{array}$ & \multicolumn{1}{l}{ Target } \\
Language
\end{tabular}

to make the translation sound equivalent and natural. This is considered an idiomatic translation that communicates the meaning from the SL to the TL and not a literal translation, as Larson (1998) states that "Meaning based translation makes every effort to communicate the meaning of the source language text in the natural form of the receptor language. Such translation is called idiomatic translation".

It can be seen that the article is not translated into the TL; the most reasonable fact is that the Indonesian language does not have indefinite or definite article in the language system, though, if it is translated literally, it becomes a quantifier (e.g the indefinite article a is translated into sebuah) and if it comes to the indefinite article the, it is often replaced by the demonstrative pronoun ini or itu in Indonesian language after the noun. Thus, the unit shift occurs resulting from the translation in the TL as a single word with no article as what the SL has.

As a result, it can be said that kunjungan is the formal correspondence of a journey as its meaning from the SL to the TL is held constant (Larson (1998). Besides, the translation product sounds natural and related to the feature of substance (Catford, 1965).

\subsection{Class Shift}

This English NP the royal houses of Europe has 5 constituents; Royal Houses as its Head NP and Europe as its M. This NP is expanded both to the left as it has a modifier before the $\mathrm{H}$ and to the right as it has a post-modifier. The internal system of the shift seems to shift in the TL.

The intra-system shift occurs here as the $\mathrm{H}$ of the SL houses is a plural noun and the translation unit keluarga implies a singular object. Therefore, the intrasystem shift occurs and the change of its system can be seen from plural to singular form as the intra-system shift happens when the term is singular in the SL and its textual equivalent is plural or vice versa (Catford (1965). The second shift occurrence is the class shift, where the $\mathrm{M}$ of the SL is Adj. and when it is translated into the TL, the word class changes into a noun; Royal (Adj.) into kerajaan (Noun). Both these shifts occur obligatorily in order to make the translation equivalent and natural.
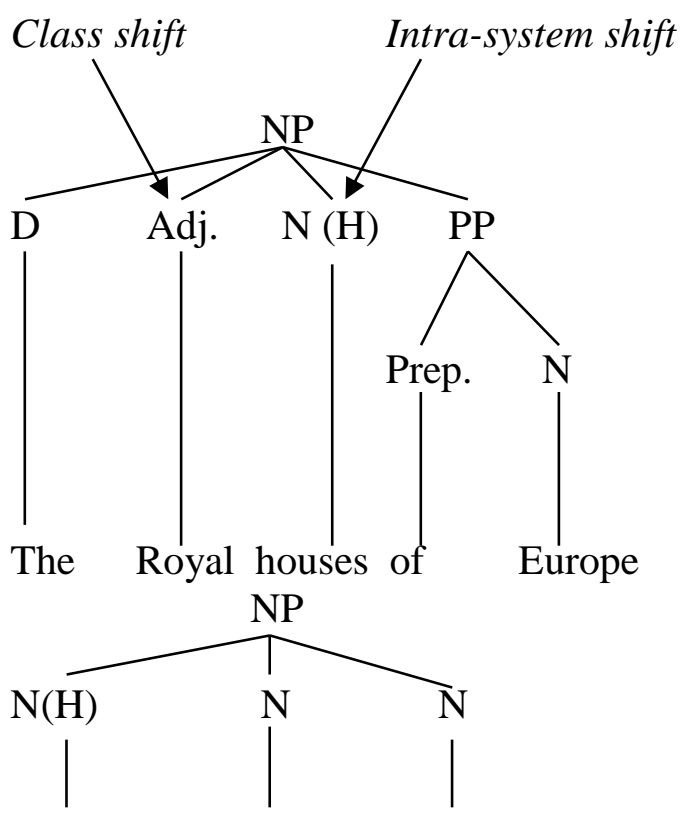

keluarga kerajaan Eropa 
According to Merriam-Webster dictionary, royal means 'of kingly ancestry' that simply means anything that is subject to crown, or a kingdom while house means 'a family including ancestors, descendants, and kindred. Altogether, the royal house describes a family that comes from a particular kingdom and, in this case, with reference to its modifier; this family is from the European Kingdom. It is translated into the TL keluarga kerajaan Eropa which is simplified into three constituents.

Royal is translated into kerajaan, though its actual meaning describes more into 'empire or kingdom' but its context is still relevant and related to the feature of the SL and Houses is translated into keluarga. There is no direct translation of Houses into Indonesian, instead the word keluarga (family) is chosen and put together as one so it produces the context of the SL. As a result, keluarga kerajaan can be said as the textual equivalence of the royal family as its meaning is related and relevant to the SL. (Catford,1965)

\subsection{Intra-system Shift}

\begin{tabular}{lllr}
\hline No & $\begin{array}{l}\text { Source } \\
\text { Language }\end{array}$ & \multicolumn{2}{l}{ Target Language } \\
\hline 01. & "By-the-way & Omong-omong, \\
since you are & karena kau & kau \\
interested in & tertarik dengan \\
these little & masalah kecil \\
problems, and & ini, dan karena \\
since you are & kau cukup bagus \\
good enough & untuk \\
to chronicle & mengisahkan satu \\
one or two of & atau \\
my trifling & pengalaman- \\
experiences, & pengalamanku \\
you may be & yang tidak \\
interested in & berharga,kau \\
this" (p.04) & mungkin akan \\
& tertarik dengan
\end{tabular}

\section{English NP Indonesian NP}

\begin{tabular}{|c|c|c|c|c|c|}
\hline $\begin{array}{l}\text { Det. } \\
\text { (Mo } \\
\text { difie } \\
\text { r) }\end{array}$ & $\begin{array}{l}\text { Adj. } \\
\text { (Mo } \\
\text { difie } \\
\text { r) }\end{array}$ & $\begin{array}{l}\text { Nou } \\
\mathrm{n} \\
\text { (He } \\
\mathrm{ad})\end{array}$ & $\begin{array}{l}\text { No } \\
\text { un } \\
\text { (He } \\
\mathrm{ad} \text { ) }\end{array}$ & $\begin{array}{l}\text { Adj. } \\
\text { (Mo } \\
\text { difie } \\
\text { r) }\end{array}$ & $\begin{array}{l}\text { Demo } \\
\text { nstrati } \\
\text { ve } \\
\text { prono } \\
\text { un }\end{array}$ \\
\hline $\begin{array}{l}\text { thes } \\
\mathrm{e}\end{array}$ & little & $\begin{array}{l}\text { Pro } \\
\text { ble } \\
\text { ms }\end{array}$ & $\begin{array}{l}\mathrm{ma} \\
\text { sala } \\
\mathrm{h}\end{array}$ & kecil & ini \\
\hline
\end{tabular}

The English NP above shows an intra-system shift. The change of its system occurs from plural to singular form. The change occurs from the SL $\mathrm{H}$ problems which shifts to the TL $\mathrm{H}$ masalah. The intra-system shift happens when the term is singular in the SL and its textual equivalent is plural or vice versa (Catford,1965). Therefore, In order to make the translation natural, the intrasystem shift occurs in the English NP these little problems into Indonesian NP masalah kecil ini. Multiple shifts occur in this shift; it can be seen that besides the intra-system shift, structure shift also occurs here. The shift occurance can be seen in the diagram below:

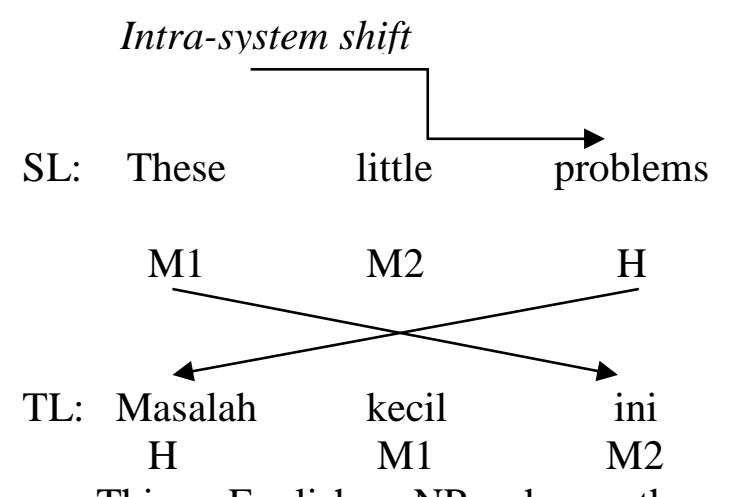

This English NP has three constituents; they are $\mathrm{M}_{1} \mathrm{M}_{2} \mathrm{H}$; it can be seen that the $\mathrm{H}$ problems is a plural noun that is preceded by the plural determiner these. The SL H problems is ended by the suffix '-s' which emphasizes that the noun is plural.

Meanwhile in Indonesian the NP problems translated into masalah which indicates a singular noun. Usually in the Indonesian language system, the plural noun would be indicated by a noun 
repetition or the addition of quantifier. It might not sound natural if it is translated into masalah-masalah kecil ini. According to the theory proposed by Alwi, et, al. a noun phrase in the Indonesian language can be expanded in the initial or the final position (left or right) as long as the formulation is ended by 'ini' or 'itu' (Alwi, et. al., 1998) which stands as the demonstrative pronoun. In this case the Indonesian NP is ended with ini which refers to the SL these to modify the $\mathrm{H}$.

As a result, it can be said that masalah is the formal correspondence of problems and the rest of the translation result sounds natural and related to the context of its SL (Catford,1965); besides the meaning is also held constant (Larson, 1998).

\section{Conclusion}

In the previous chapter, the analysis of the types of shifts and their implication on the meaning equivalent was performed. Based on the analysis and discussion, the following points can be drawn as conclusions:

As a matter of fact, translation shift has been one of the translation elements that is essential and often found in any kind of translation. There are four kinds of shifts occurring in the translation namely structure shifts totalling 10 ; unit shift totalling 7 , class shifts totalling 1 and intra system-shifts totalling 3 shifts. All of them belong to the category shift, the second type of translation shift. It can be seen that each type of the shift comprises a few English NPs as the most frequent shift; the least one is the class shift.

\section{Bibliography}

Catford, J. C. (1965). A Linguistic Theory of Translation. London: Oxford University Press, London.
Darmapati, Aris. (2017). Shifts

(Translation Shifts).

[Internet]Available on

http://englishdecode.blogspot.co.i $\mathrm{d} / \mathrm{p} /$ definition-of-translationshifts.html [accessed 4th July 2018]

Et, al. Alwi. (1988). Tata Bahasa Baku Bahasa Indonesia (TBBI). Balai Pustaka, Jakarta.

Et, al.Quirk. (1973). A University Grammar of English. Longman, England.

Hosseini-Maasoum Seyed Mohammad, Dr. (2013).

Translation Shifts in the

Persian Translation of a Tale of Two Cities by Charles Dickens, Iran.

Kurnianto, Hanif. (2015).Unit Shift in Spiderman 2 English Movie Text and The Bahasa Indonesia Subtitling Text (Thesis). Yogyakarta State University, Yogyakarta.

Radford, A. (2004). English syntax: An Introduction. Cambridge University Press, Cambridge.

Satwika, I.G.A Agung Shinta. (2012). The Translation of English Noun Phrase into Indonesian in The Novel "Family Album (thesis). Udayana University, Denpasar. 